\title{
Corelation between Communication Skills and Motivation of Teachers
}

\author{
Research Article
}

\section{Selcuk SIMSEK¹, Ali Riza ERDEM²}

${ }^{1}$ Pamukkale University, Faculty of Education, Department of Primary Education, Denizli, Turkey, ORCID: 0000-0002-4546-7945

2 Adnan Menderes University, Faculty of Education, Department of Educational Sciences, Aydın, Turkey, ORCID: 0000-0001-9704-9529

To cite this article: Simsek, S., \& Erdem, A. R. (2020). Corelation between Communication Skills and Motivation of Teachers, International Online Journal of Educational Sciences, 12 (3), 1-9.

\section{ARTICLE INFO \\ Article History: \\ Received: 08.12.2019 \\ Available online: 14.05.2020}

\begin{abstract}
The aim of this study is to identify to what extend gender, experience, education status and field of study predict the correlation between communication skills and motivation of teachers and reveal the correlation between communication skills and motivation. The target population of the study consists of teachers working in state schools from preschools, primary schools, secondary and high schools in Pamukkale and Merkezefendi which are central districts of Denizli province. 726 teachers were selected from target population using proportional sampling method. Data were collected using "Teacher Communication Skills Scale" developed by Çetinkanat (1997) and "Inventory of Factors Affecting Teacher Motivation" developed by Yildirım (2006). At the end of the administration, Cronbach Alpha reliability coefficient for "Teacher Communication Skills Scale" and "Inventory of Factors Affecting Teacher Motivation" was found 0.93 and 0.97 respectively. Data were analyzed using multiple regression and Pearson correlation coefficient techniques with the help of SPSS for Windows (Statistical Packages for Social Sciences). At the end of the study it was identified that experience is a significant predictor of teachers' communication skills. It was seen that gender is a significant predictor of teacher motivation. A positive and low-level significant correlation between communication skills and motivation of teachers was identified.
\end{abstract}

(ㄷ) 2020 IOJES. All rights reserved

Keywords:

Teacher, communication skills, motivation, prediction, correlation

\section{Introduction}

Changes took place in science, technology and knowledge in the $21^{\text {st }}$ century have been forcing humanity to develop themselves in terms of their knowledge, skills, values, behavior and attitudes. According to Teo (2019) communication, cooperation and critical thinking are among the skills that were called "real global skills" in the $21^{\text {st }}$ century. One of these skills is communication which is an essential skill in human interaction. Maeetta (1999) stated that communication is the driving force in any relationship or situation. Halimah \& Sukmayadi (2019) suggested that communication is a way of information exchange through

${ }^{1}$ Corresponding author's address: Pamukkale University, Faculty of Education

Telephone: +902582961139

e-mail: selcuks@pau.edu.tr

DOI: https://doi.org/10.15345/iojes.2020.03.001 
interaction among people. Dökmen (2005) defined it as production, transfer and understanding of information. The elements of communication, which is a complex, symbolic, comprehensive, interactive process, are source, message, channel, receiver and feedback (Erdem and Okul, 2015). Communication skill, which includes at least two individuals, can be acquired in the right way in an education institution primarily. Teachers are the ones who will help individuals to gain communication skills. They help the individual to gain communication skill using both theoretical and practical education.

Communication skills that a teacher has to help every individual gain through the activities he leads in educational institutions are valid for teachers as well. According to Burleson and Samter (1990) claimed that every individual including teachers should gain the following communication skills; conversational skill (the ability to start, maintain and terminate pleasant everyday talks), referential skill (ability to transfer information clearly and unambiguously), ego supportive skill (ability to make other feel good about himself/herself), comforting skill (the ability to make others feel better when depressed, sad, or upset), conflict management (the ability to reach mutually satisfying solutions in conflicts), persuasive skill (the ability to get people to modify their thoughts and behaviors), narrative skill (the ability to entertain through jokes, gossip, stories, etc.), and regulation (the ability to help someone who has violated a norm to fix the mistake effectively) (in Frymier \& Houser, 2000). Communication skills such as conversational, persuasive, comforting, referential and narrative skills should have been acquired by teachers.

Teachers have to use communication as an effective tool while enabling students socialized in educational institutions. Tepeli and Arı (2011) suggested that teaching profession is a communication job and education is a communication activity. Teachers need to form effective communication with their students while performing their duties. According to Can and Dursun (2019) teachers should be able to form "good dialogue" with their students. Gaining "effective communication" skill is among the general teacher competencies determined by Ministry of National Education [MEB] (2017). Gürşimşek (1999) defined being a teacher who could form effective communication as avoiding judgmental messages, trying to understand feelings, avoiding tagging and labeling, using praising carefully, cooperation and reflecting emotions.

Teachers' competency in communication skills would initially ensure cooperation among teachers, then a health communication with the staff in the school and finally integration with the students. Tepeli and Ar1 (2011) argued that in order to achieve an effective learning-teaching process, forming a special teacher-student interaction is necessary. Halimah and Sukmayadi (2019) reported that conducted studies indicated a positive correlation between teachers with excellent verbal communication skills and students' high academic achievements. Having inadequate communication skills would impede teaching-learning process, effective communication among teachers, teacher student interaction and interaction with others. Teachers should prioritize communication skills both for themselves and in terms of enabling students to gain these skills. Çelikkaya, Yıldırım and Kürümlüoğlu (2019) asked students and teachers about ordering the skills to be attained, students ranked communication skills at the first place and teachers in the second place. All teachers on duty should have been equipped with communication skills. Bulut (2004) reported that total communication skills scores of teachers with 11-15-year experience are high and mean communication skills scores of teachers with 0-5-year experience are low. Durukan and Maden (2010) stated that Turkish language teachers generally had low communication skills. When the studies concerning communication skills were reviewed, it was concluded that female teachers had higher communication skills than male teachers (Şeker, 2000; Saracaloğlu, Silkü and Özkütük, 2001; Ceylan, 2007; Özerbaş, Bulut and Usta, 2007; Toy, 2007).

In addition to have communication skills, teachers also need motivation. Din et.al. (2012) defined motivation as a skill and desire of an individual to reach an aim, do something and meet the needs. Aslamiah and Saleh (2019) interpreted motivation as a driving force for a person to engage in certain activities to achieve certain goals generally. Teachers should be motivated in order to perform the responsibilities they took in the 
best way. According to Coker, Kiefer, and Robinson (2019) it is important to understand how teacher motivation would affect teachers' perceptions about classroom learning atmosphere and their beliefs in teaching process. Balyer and Çetindere (2019) claimed that teachers need to have high motivation to provide good education, produce innovative ideas and keep up with the changing world. Motivation level varies among teachers as the internal and external factors that motivate a teacher differ. External factors can be defined such as rewards, punishment, praise, promotion, salary etc. from external environment. Internal sources of motivation are curiosity, interest, learning needs, competency and development feelings etc. (Yazıc1, 2009; Timuroğlu and Balkaya, 2017).

There are numerous factors affecting teacher motivation. Yazıc1 (2009) stated that the factors that affect teacher motivation can be summarized as physiological needs, self-realization and self-control, achievement needs and autonomy. Teachers having high motivation level can be explained with meeting needs about oneself and having an environment where he could express himself. Moreover, experiencing the feeling of success is another important factor. Being able to feel free and autonomous can be considered as important factors in high teacher motivation levels. Because the more comfortable a teacher feels himself/herself both mentally and physically the higher motivation level she/he would have. According to Berhanu and Sabanc1 (2019) the strategies that increase the motivation of the teacher sucha as; giving award(s), supporting their ideas, recognizing their efforts, making participatory decisions, creating a positive school climate, enabling them to share their experiences, empowering the teacher and giving autonomy will increase their motivation. Taş and Korkmaz (2019) stated that professional competency and experience, professional development and promotion, professional prestige are among the factors that motivate primary school teachers the most.

Importance of communication skills and motivation for teachers in terms of their profession can be seen in the results of conducted studies. While communication is considered to be basis for the profession, motivation has a key role in making teachers to feel better and have an autonomous atmosphere. There are studies about the correlation between teachers' communication skills and motivation. In the study conducted by Ertürk and Aydın (2017) it was reported that having high communication skills was listed among the factors that increase the motivation of teachers. According to the gathered finding, it can be claimed that there is a strong correlation between motivation and communication. There are study results concerning the correlation between gender and motivation level. Ertürk and Aydın (2017) reported that intrinsic motivation level of female teachers was higher than male teachers. According to Cansu and İrge (2019) motivation of female teachers is higher when compared to male teachers. On the other hand, there are limited number of studies that predict teachers' communication skills and motivation according to independent variables so this study is expected to contribute to the literature.

The aim of this study is to identify to what extend gender, experience, education status and field of study predict the correlation between communication skills and motivation and reveal the correlation between communication skills and motivation. Findings of this study concerning the correlation between teachers' communication skills and motivation might contribute to increase the teacher competencies.

\section{Method}

In this study correlational screening design was utilized. Correlational survey design aims to examine the change or the level of change between two or more variables (Fraenkel \& Wallen, 2009; Karasar, 2019). The target population of the study consists of teachers working in state schools from preschools, primary schools, secondary and high schools in Pamukkale and Merkezefendi that are central districts of Denizli province. As it is imposible to reach all target population 726 teachers were chosen from the target population using proportional sampling method. Teacher Communication Skills Scale developed by Çetinkanat (1997), Inventory of Factors Affecting Teacher Motivation developed by Yıldırım (2006) and personal information form consisting of four questions were used as data collection instruments. 


\section{Teacher Communication Skills Scale}

In order to ask teachers' opinions about communication skills "Teacher Communication Skills Scale" developed by Çetinkanat (1997) was used. The scale was developed based on the principles of psychology and psychotherapy about communication skills in healthy human interaction. The scale consists of 44 Likert type items ( 1 never 2 rarely 3 sometimes 4 most of the time 5 almost always 6 always). As the items 2, 23, and 40 have negative expressions they were scored reversely. Teachers chose one of the options that was suitable for them. Agreement level gaps calculated using $(n-1: n)$ formula. At the end of the calculation the gap width between 1 and 6 was found 0,83. Choice gap for each item was taken as 1.00-1.82 for "never", 1.83-266 for "rarely", 2.67-3.50 for "sometimes", 3.51-4.34 for "most of the time", 4.35-5.18 for "almost always" and 5.18-6.00 for "always". Cronbach Aplha value for the "Teacher Communication Skills Scale" developed by Çetinkanat (1997) was found 0.81. Cronbach Alpha for the current study was found 0.93.

\section{Inventory of factors affecting teacher motivation}

In order to get teachers' ideas about the factors that motivate teachers "Inventory of Factors Affecting Teacher Motivation" which was developed by Yıldırım (2006) was used. The inventory was developed based on to what extend encouraging tools, opportunities and environments motivate teachers. Teachers chose one of the options that was suitable for them. Agreement level gaps calculated using $(n-1: n)$ formula. At the end of the calculation the gap width between 1 and 6 was found 0.83 . Choice gap for each item was taken as 1.001.82 for "never", 1.83-2.66 for "rarely", 2.67-3.50 for "sometimes", 3.51-4.34 for "most of the time", 4.35-5.18 for "almost always" and 5.18-6.00 for "always". Cronbach Aplha value for "Inventory of Factors Affecting Teacher Motivation" developed by Yıldırım (2006) was found 0.94. In this study Cronbach Alpha was found 0.97.

Multiple regression technique was utilized to identify prediction level of gender, experience, educational status and field of study variables teachers' communication skills and motivation. One sample Kolmogorov-Simirnov test was run to identify the normality of disribution and decide which statistical technique to use while identifying the correlation between teachers' communication skills and motivation. At the end of $\mathrm{K}-\mathrm{S}_{(\mathrm{z})}$ analysis results, it was seen that "Teacher Communication Skills Scale" variable had a normal distribution $\left[\mathrm{K}-\mathrm{S}_{(\mathrm{z})}=1.097\right.$; $\left.\mathrm{p}: 0.180\right]$ but "inventory of factors affecting teacher motivation" did not have a normal distribution[K-S(z) $=1,954 ; \mathrm{p}: 0,001]$. As a result, while analyzing gathered data to identify the correlation between teachers' communication skills and motivation Pearson corelation coefficient technique was used.

\section{Findings and Comments}

In the study multiple regression analysis was conducted to find out whether gender, experience, educational status and field of study variables predict teachers' communication skills significantly. Findings are presented in Table 1.

Table 1. Significance values of gender, experience, education status and field of study in predicting teachers' communication skills (Multiple regression analysis)

\begin{tabular}{|c|c|c|c|c|c|c|}
\hline Variables & & B & SНв & $\beta$ & $\mathbf{t}$ & $\mathrm{p}$ \\
\hline Dependent & & 4,807 & 0,132 & - & 36,466 & 0,000 \\
\hline Gender & & $-0,078$ & 0,041 & $-0,076$ & $-1,912$ & 0,056 \\
\hline Experience & & 0,093 & 0,025 & 0,144 & 3,661 & 0,000 \\
\hline Education Status & & 0,054 & 0,053 & 0,039 & 1,022 & 0,307 \\
\hline \multirow[t]{2}{*}{ Field of Study } & & $-0,007$ & 0,019 & $-0,014$ & $-0,350$ & 0,726 \\
\hline & $\mathrm{R}=0,144$ & $\mathrm{R}^{2}=0,021$, & $\mathrm{F}=3,827$, & $\mathrm{p}=0,004$ & & \\
\hline
\end{tabular}

$\mathrm{p}<0.01$ 
When Table 1. is examined it can be seen that gender, experience, educational status and field of study variables are significant predictors of teachers' communication skills. These variables together explain $2 \%$ of the total variance of teachers' communication skills $\left[R=0,144 ; R^{2}=0,021\right.$ ve $\left.p<0.01\right]$. According to standardized regression coefficient $(\beta)$, predictor variables' subjective significance order over teachers' communication skills is in the following way; experience, gender, education status and field of study. When the significance of regression coefficients were examined, it was seen that only experience was a significant predictor of teachers' communication skills. This finding can be interpreted as experience is a more important variable in predicting teachers' communication skills. Other variables; namely gender, education status and field of study are insignificant in predicting teachers' communication skills. At the end of regression analysis results, regression equality for the prediction of teachers' communication skills was in the following way; teachers' communication skills $=4,807+0,093$ experience $+-0,078$ gender $+0,054$ education status $+-0,007$ field of study.

In the study multiple regression analysis was run to see whether gender, experience, educational status and field of study variables predict teachers' motivation significantly. Findings are given in Table 2.

Table 2. Significance values of gender, experience, education status and field of study in predicting teachers' motivation (Multiple regression analysis)

\begin{tabular}{|c|c|c|c|c|c|c|}
\hline Variables & & B & SНв & $\beta$ & $t$ & $\mathrm{p}$ \\
\hline Dependent & & 5,119 & 0,252 & - & 20,318 & 0,000 \\
\hline Gender & & $-0,322$ & 0,078 & $-0,162$ & $-4,128$ & 0,000 \\
\hline Experience & & $-0,023$ & 0,049 & $-0,018$ & $-0,473$ & 0,636 \\
\hline Education Status & & 0,080 & 0,101 & 0,030 & 0,794 & 0,427 \\
\hline \multirow[t]{2}{*}{ Field of Study } & & $-0,069$ & 0,037 & $-0,074$ & $-1,850$ & 0,065 \\
\hline & $\mathrm{R}=0,205$ & $\mathrm{R}^{2}=0,042$, & $\mathrm{F}=7,913$ & $\mathrm{p}=0,000$ & & \\
\hline
\end{tabular}

$\mathrm{p}<0.01$

It is seen in Table 2. that gender, experience, educational status and field of study variables are significant predictors of teachers' motivation. These variables altogether explain $4 \%$ of the total variance in teachers' motivation $\left[R=0,205 ; R^{2}=0,042\right.$ ve $\left.p<0.01\right]$. According to standardized regression coefficient $(\beta)$, predictor variables' subjective significance order over teachers' motivation is in the following way; gender, field of study, education status and experience. When the significance of regression coefficients was examined, it was seen that only experience gender was a significant predictor of teachers' motivation. This finding can be interpreted as gender is a more significant variable in predicting teachers' motivation. Experience, educational status, and field of study variables are not significant in predicting teachers' motivation. At the end of regression analysis results, regression equality for the prediction of teachers' motivation was in the following way; teachers' motivation $=, 119+-0,322$ gender $+0,080$ educational status $+-0,069$ field of study +0,023 experience.

In order to identify the correlation between teachers' communication skills and motivation Pearson corelation coefficient technique was utilized. The results were presented in Table 3.

Table 3. Correlation between teachers' communication skills and motivation (Pearson Corrrelation Coefficient)

\begin{tabular}{llrr}
\hline & & $\begin{array}{r}\text { Teachers' } \\
\text { communication skills }\end{array}$ & Teachers' motivation \\
\hline Teachers' communication skills & Pearson Correlation & 1,000 & $0,209^{*}$ \\
& Sig. (2-tailed) & & 0,000 \\
& $\mathrm{~N}$ & 726 & 726 \\
\hline Teachers' motivation & Pearson Correlation & $0,209^{*}$ & 1,000 \\
& Sig. (2-tailed) & 0,000 & 726 \\
\hline $\mathrm{p}<0.01$ & $\mathrm{~N}$ & 726 & \\
& & &
\end{tabular}


When Table 3. is examined, it is seen that there is statistically a positive weak correlation between teachers' communication skills and motivation $[\mathrm{r}=0,209 ; \mathrm{p}<0.01]$. Consequently, there is a positive correlation between teachers' communication skills and motivation and when their communication skills increase their motivation increase at a low level.

\section{Discussion and Results}

First important finding of the study is that the most significant variable in predicting teachers' communication skills is "experience". In other words, teachers' experience and seniority in their profession is an important factor in predicting their communication skills. According to the study, more experienced teachers' communication competencies are higher when compared to less experienced teachers. Şeker (2000) reported that communication skills of teachers with less experience was weak while teachers with 16-25 years had better communication skills. Similarly, according to the e study conducted by Bulut (2019) it was claimed that teachers with 1-5-year experience had lower communication scores than teachers with 6-10-year experience. Şara and Güney (2015) stated that scores on behavioral aspects of communication skills of teachers having 6-10 years of seniority differ significantly from other teachers. Şimşek and Bakır (2019) found out that teachers who had 21 years and over experience had more eye contact with students while talking or lecturing them when compared to other teachers.

Another important finding of the study is that "gender" is the most significant factor in predicting teachers' motivation. According to this finding, whether a teacher is a male or female is an important factor in predicting motivation. In the study it was concluded that female teachers' motivation level was higher when compared to males. Ertürk and Aydın (2017) reported that intrinsic motivation level of female teachers was higher than male teachers. According to Güloğlu Demir, Demir and Bolat (2017) general motivation of female teachers is higher. Arslantaş, Tösten and Marakçı (2018) interpreted that there is an insignificant difference in professional motivation in terms of gender as target teachers have similar characteristics. Cansu and İge (2019) female teachers have a higher level of motivation than male teachers. Female teachers were affected more from motivation tools while teaching and therefore they avoided less from teaching profession than males (Demirkol, 2019). Taş and Korkmaz (2019) stated that professional prestige motivates female primary school teachers more than males. İlğan \& Ceviz (2019) suggested that professional motivation level of female teachers is higher than male teachers. On the other hand, Canöz, Ünlü and Uzunkol (2019) reported that motivation levels of teachers did not differ in terms of gender variable.

According to the third important finding of the study, corelation between the communication skills and motivation of the teacher in fulfilling his / her responsibilities in the profession was positive but low. This finding means that when the competencies of a teacher related to his/her communication skills improve, his/her motivation will not also increase in direct proportion. In other words, it can be claimed that not only communication skills but also other skills are effective in increasing teachers' motivation. However, this does not reduce the importance of communication skills in fulfilling the responsibilities of a teacher, but rather increases them. In the study conducted by Ertürk and Aydın (2017) mentioned that having high level of communication skills was among the factors increasing motivation of teachers.

First finding of the study has shown that when experience of teachers increases, their communication skills change in a positive way. This can be interpreted as professional experience is a significant variable in predicting communication skills of teachers. Second finding of the study was that motivation of teachers differ in terms of gender. Conducted studies have shown that motivation of female teachers is higher than male teachers. Another important finding of the study is that there is a positive but low correlation between communication skills of teachers and their motivation levels. According to this finding, when competencies of the teachers related to their communication skills improve their motivation might increase even at a low level. 


\section{REFERENCES}

Arslantaş, H. İ., Tösten, R. \& Marakçı, D. B. (2018). Professional motivation elements of high school teachers: a mixed method study. Mersin University Journal of Education Faculty, 14(3), 880-895, DOI: $10.17860 /$ mersinefd.485161.

Aslamiah, A. I. \& Saleh, M. (2019). Relationship between the principal role, motivation and satisfaction with the performance of elementary school teachers. Journal of Education, and Management, 2(2), 87-96.

Balyer, A. \& Çetindere, E.D. (2019). Examining the relationship between teachers' organizational silence perception and motivation. Yildiz Journal of Educational Research, 3(2), 99-116.

Berhanu, K. Z. \& Sabanc1, A. (2019). Factors influencing teachers' motivation and strategies taken to improve their motivation by princıpals: Ethiopia as a sample. Mehmet Akif Ersoy University Journal of Education Faculty, 52, 237-260.

Bulut, R. C. (2019). Relationship between communication skills and organizational cynicism levels of secondary school teachers. Unpublished Master's Thesis, Sabahattin Zaim University Social Sciences Institute, İstanbul.

Bulut, B, N. (2004). Investigation of primary school teachers' perceptions about communication skills in terms of various variables. The Journal of Turkish Educational Sciences, 2(4), 443-452. Retrieved from https://dergipark.org.tr/tr/pub/tebd/issue/26126/275206.

Can, Y. \& Dursun, F. (2019). English language teachers' qualifications according to $11^{\text {th }}$ and $12^{\text {th }}$ language class students, The Journal of International Lingual, Social and Educational Sciences, 5(1), 75-91.

Canöz, T., Ünlü, İ. \& Uzunkol, E. (2019). Examination of vocational motivation levels and classroom management styles of primary school teachers. Journal of Primary Education, 1(2), 40-56.

Cansu, R. \& İrge, N. T. (2019). The effect of school administrators showing innovative management characteristics on teachers' motivation and organizational commitment. Corporate Governance and Sustainability Symposium 2019, 8 May 2019, İstanbul Aydın University.

Ceylan, G. (2007). The effect of teacher-student interaction on classroom atmosphere (Aksaray province case). Unpublished Master's Thesis, Selçuk University Social Sciences Institute, Konya.

Coker, J., Kiefer, S. \& Robinson, R. (2019). Teacher motivation profiles: Implications for teacher beliefs and perceptions of the classroom environment. Advances in Global Education and Research, 3, 267-278.

Çelikkaya, T., Yıldırım, T. \& Kürümlüoğlu, M. (2019). Ability hierarchies, reasons and recommendations of students and social studies teachers regarding ability in social studies curriculum. MANAS Journal of Social Studies, 8(1), 113-134.

Çetinkanat, C. (1997). Communication skills of teachers. $3^{\text {rd }}$ National Classroom Teaching Symposium, 23-24 October 1997, Adana.

Demirkol, M. (2019). The motivation levels of primary school teachers for preceptorship, Academia Journal of Educational Research, 4(1), 37-54. https://dergipark.org.tr/tr/pub/egitim.

Din, M. N. U., Tufail, H., Shereen, S., Nawaz, A. \& Shahbaz, A. (2012). Factor affectıng teacher motıvatıon at secondary school level in Kohat city. Interdisciplinary Journal of Contemporary Research in Business, 3(10), $442-449$.

Dökmen, Ü. (2005). Communication conflicts and empathy. İstanbul: Sistem Publishing

Durukan, E. \& Maden, S. (2010). A study on communication skills of Turkish teachers. Journal of Social Sciences Research, 5(1), 59-74. 
Erdem A. R. \& Okul, Ö. (2015). Primary school teachers' communication skills with students, Journal of Contemporary Administrative Science, 1(1), 1-8.

Ertürk, R. \& Aydın, B. (2017). Investigation of the situations that increase the motivation of the teachers and negatively affect them. The Journal of Academic Social Science, 5(58), 582-603.

Fraenkel, J. R. \& Wallen, N. E. (2009). How to design and evaluate research in education (Seventh ed.). New York: McGraw-Hill.

Frymier, A. B. \& Houser, M. L. (2000) The teacher-student relationship as an interpersonal relationship. Communication Education, 49(3), 207-219. DOI: 10.1080/03634520009379209

Güloğlu Demir, C., Demir, E. \& Bolat, Y. (2017). The relationship between characteristics of primary school teachers and their motivations. Mustafa Kemal University Journal of Social Sciences Institute, 14(37), 73-87.

Gürşimşek, I. (1999). Effective communication skills for effective classroom management. Education and Science, 23(112), 40-44.

Halimah, L. \& Sukmayadi, V. (2019). The role of "Jigsaw" method in enhancing Indonesian prospective teachers' pedagogical knowledge and communication skill. International Journal of Instruction, 12(2), 289304. https://doi.org/10.29333/iji.2019.12219a

İlğan, A. \& Ceviz, H. (2019). The relationship between the perception of the society related to teaching profession and teachers' professional motivation according to teachers view. Educational Administration in Theory and Practice, 25(2), 285-338. Doi: 10.14527/kuey.2019.008.

Karasar, N. (2019). Scientific research method: Concepts, principles, techniques (34 ${ }^{\text {th }}$ Edition). Ankara: Nobel Academic Publishing

Maeetta B.J. (1999). Communication in the classroom. U.S. Department of EducationOffice of Educational Research and Improvement. http://ericfac.piccard.csc.com/reprod.ht.

MEB. (2017). General competencies of teaching profession. General Directorate of Teacher Training and Development, Ankara.

Özerbaş, M. A., Bulut, M., \& Usta, E. (2007). Examining the levels of perceived communication skills of prospective teachers. Ahi Evran University Journal of Kırşehir Faculty of Education, 8(1), 123-135.

Şara, P. \& Güney, Ü. (2015). A study of primary and secondary teachers' communicative skill levels in terms of various factors: Sample case Esme. Bartin University Journal of Faculty of Education, Special Issue on XIV. International Participation Symposium of Primary School Teacher Education (21-23 May 2015), 195 $-205$.

Saracaloğlu, A.S., Silkü, A. \& Özkütük, N. (2001). Prospective teachers' communication skills. X. Educational Sciences Congress, Bolu Abant İzzet Baysal University Proceedings Book, Volume 3, 1754-1762.

Şeker, A. (2000). Examination of the relationship between classroom teachers' communication skills and classroom atmosphere in terms of various variables. Unpublished Master's Thesis, Selçuk University Social Sciences Institute. Konya.

Şimşek, A. \& Bakır, S. (2019). Investigation of nonverbal communicatıon behaviors of Turkish teachers. International Journal of Turkish Literature Culture Education, 8(2), 1099-1118.

Taş, S. \& Korkmaz, İ. (2019). Describe the factors which influence the classroom teachers motivation (Sample of Konya), Sportive, 2(1), 12-24. 
Teo, P. (2019) Teaching for the $21^{\text {st }}$ century: A case for dialogic pedagogy. Learning, Culture and Social Interaction, $21,170-178$.

Tepeli, K. \& Arl, R. (2011). Comparative examination of communication and social skills of teachers and teacher candidates in pre-school education. Selçuk University Journal of Social Sciences Institute, 26, 385394.

Timuroğlu, M. K. \& Balkaya, E. (2017). The relationship between organizational communication and motivation: An application. Uludağ University Journal of Social Sciences Institute, 9(2), 89-113.

Toy, S. (2007). Comparison of engineering and law faculty students in terms of communication skills and examination of communication skills and some variables, Unpublished Master's Thesis, Ankara University Social Sciences Institute, Ankara.

Yazıc1, H. (2009) Teaching profession sources of motivation and basic attitudes: A theoretical overview. Journal of Kastamonu Education, 17(1), 33-46.

Yıldırım, D. Ş. (2006). Factors affecting motivation and job satisfaction of teachers working in official primary schools. Unpublished Master's Thesis, Yeditepe University Social Sciences Institute, İstanbul. 